No. $9 / 03$

\title{
Where Do Banks Expand Abroad? An Empirical Analysis
}

\author{
by \\ Dario Focarelli \\ Bank of Italy, Research Dept. \\ and \\ Alberto Franco Pozzolo \\ University of Molise, Dept. SEGeS
}




\title{
Where Do Banks Expand Abroad?
}

\author{
An Empirical Analysis
}

\author{
by Dario Focarelli and Alberto Franco Pozzolo*
}

\begin{abstract}
$\underline{\text { Abstract }}$
This paper investigates the determinants of the pattern of banks' foreign investment. We extended previous analyses in three directions. First, we use a unique database that includes information on 260 large banks from OECD countries and all their foreign branches and subsidiaries in each one of the other OECD countries. Second, we consider explicitly the role of institutional and regulatory characteristics. Third, we considered within a unified framework a wide set of variables that are likely to influence the pattern of bank internationalization. Consistent with previous research, we find that a high degree of integration between the home and the destination countries has an effect on the location choice of multinational banks. However, we also find that the marginal effect of integration is much lower than that of other explanatory variables. Profit opportunities resulting from a high expected economic growth and the prospect of competing with relatively less efficient banks appear to be a key factor affecting the expansion abroad, especially in the case of subsidiaries. Institutional characteristics of the destination country also play a crucial role. For example, financial centers attract branches of foreign banks, but not subsidiaries, while lower regulatory restrictions on banking activities are associated with a stronger presence of foreign subsidiaries, but not of branches.
\end{abstract}

JEL-classification: E30, G21, F21, F23.

keywords: international banking, foreign direct investment

\footnotetext{
* Focarelli: Banca d'Italia, Research Department. Pozzolo: University of Molise and Ente Luigi Einaudi. Opinions expressed are those of the authors and do not necessarily reflect those of the Banca d'Italia. For comments and suggestions we thank Jason Abrevaya, Allen Berger, Claudia Buch, Nicola Cetorelli, Luca De Benedictis, Robert DeYoung, Michele Gambera, Hesna Genay, Giorgia Giovannetti, Giorgio Gobbi, Luigi Guiso, Anil Kashyap, George Kaufman, Lucia Piscitello, Fabio Panetta, Luigi Zingales, an anonymous referee and seminar participants at the Banca d'Italia, at the Federal Reserve Bank of Chicago, at the Finance Brown Bag lunch of the University of Chicago, at the 2nd Kiel Workshop in Economics, at the $36^{\text {th }}$ Annual Conference on Bank Structure and Competition of the Federal Reserve Bank of Chicago, at the 2000 European Economic Association Congress, at Ente Einaudi and at the June 2002 CNR meeting on international and development economics in Alghero. This paper was written while Alberto Pozzolo was mainly with the Research Department of Banca d'Italia. Address for correspondence: Dario Focarelli, Banca d'Italia, Servizio Studi, Via Nazionale 91, 00184, Rome, Italy. Tel.: +39-06-47921 Fax: +39-06-47923723 E-Mail: focarelli.dario@insedia.interbusiness.it.
} 


\section{Introduction}

International banking has gone through alternate fortunes in the last 150 years. It was very common at the end of the XIX century, when foreign banks were deeply involved in financing large investment abroad, in particular towards colonies; it declined during the inter-war period, only to reemerge in the 1970s, following financial innovation and the rapid increase in international trade. In recent years, international banking activities have reached a historical peak, thanks also to an increase in crossborder mergers (see, for example, Berger et al. 2000).

The strong expansion in banks' internationalization observed in recent years is raising a number of questions about its determinants and its possible effects on the shape of the banking industry. There are essentially three ways that banks can follow in order to extend their activities abroad: providing loans and asset and liability management to foreign counterparts, opening a foreign branch, and acquiring shareholdings in a foreign bank (subsidiary). ${ }^{1}$ Direct lending is typically offered to largescale borrowers, such as states and multinational companies, often in the form of syndicated loans. It does not require the physical presence of the bank in the foreign country, although representative offices may prove useful. Foreign branches are an integral part of the parent bank and can offer a broad range of banking services to both domestic and foreign customers. Traditionally, their activity is primarily concentrated in the wholesale market. Finally, subsidiaries have identical banking powers as domestic banks and are typically retail oriented.

This paper concentrates on the two strategies of expansion that require a physical presence abroad: branching and acquisition of subsidiaries. In fact, although banks with their head offices in foreign countries may have a comparative advantage with respect to the quality of the financial services they offer, they are very unlikely to be in a better position when it comes to building relationships with local clients. A physical presence can be considered a precondition for developing personal 
relationships, which remain fundamental for most traditional banking activities (see, for example, Rajan, 1998).

The development of foreign branches and subsidiaries in the last 40 years has been largely uneven. Foreign branching can be considered a more mature form of expansion abroad. According to Brealey and Kaplanis (1996), the number of banks' foreign branches increased very rapidly from about 1960 to the mid-1980s and slowed significantly after $1985 .^{2}$ In contrast, the number of cross-border mergers and acquisitions in the banking industry has risen most rapidly in the 1990s. However, they are still a small fraction of banking M\&A activity within individual nations (Group of Ten, 2001) and they are rarer than in other industries (Focarelli and Pozzolo, 2001).

Three major factors explaining the pattern of bank internationalization have been identified in the empirical literature: economic integration, institutional characteristics and profit opportunities. It is a well accepted fact in the economic literature that the pattern of bank internationalization is correlated with the degree of integration between the home country of the parent company and the country where the branch or the subsidiary is located. Integration relates both to strictly economic variables, such as the levels of trade or foreign direct investment, and to non-economic aspects, such as linguistic and cultural similarities. ${ }^{3}$

Regulatory restrictions also significantly affect how banks configure their international activities. Governments, for example, may reduce the degree of cross-border consolidation either directly, by putting explicit limits on cross-border M\&As or blocking single takeovers, or indirectly, by failing to harmonize structural differences among the financial systems or imposing limits on domestic banking activity. ${ }^{4}$ Moreover, the characteristics of the banking sector can also affect the probability of entry. Boot (1999), for example, argues that governments may wish to have the largest institutions in their nations domestically owned. If this is the case, it can be expected that in more concentrated markets the entry of foreign banks will be more difficult, because one single acquisition would imply the loss of a significant share to the advantage of foreign investors. ${ }^{5}$ 
Profit opportunities are probably the most basic determinant of the pattern of bank internationalization. These can be related to bank-specific factors, to the characteristics of the country of origin of the investing bank, and to the characteristics of the country of destination of the investment. Among bank-specific characteristics, size has been found to affect mainly the patterns of internationalization: larger banks are much more international than smaller ones, most likely because they have larger and more internationally diversified customers (Berger et al., 1995), they have stronger incentives to diversify internationally their portfolio and to smooth the effects of asynchronous fluctuations in loans and deposits, they are involved in activities, such as portfolio management and investment banking, that are typically international and are characterized by economies of scale and scope. ${ }^{6}$ Among home country characteristics, those with a stronger effect on the pattern of bank internationalization relate to the development of the financial markets. In fact, banks that operate in developed markets are likely to be more efficient and therefore to hold a comparative advantage with respect to their competitors in the destination country. ${ }^{7}$ Finally, although no conclusive empirical evidence has been so far provided on their importance, profit opportunities in the destination market of investment have been related to country risk (Grosse and Goldberg, 1991; Fisher, and Molyneux, 1996; Yamori, 1998), the size of the banking financial sector (Goldberg and Grosse, 1994), income per capita (Goldberg and Johnson, 1990; Claessens et al., 2000; Yamori, 1998), and total income (Brealey and Kaplanis, 1996; Buch, 2000).

Economic integration, institutional characteristics and profit opportunities are indeed the driving forces of bank internationalization, but their effect may be different depending on the expansionary policy followed by the bank. ${ }^{8}$ For this reason, in our empirical analysis we distinguish between foreign branches and foreign subsidiaries. Our sample includes 260 large banks from OECD countries and all their foreign branches and subsidiaries in each one of the other OECD countries. By comparing within a unified framework the determinants of alternative expansionary policies we are able to gather further insights into the prospects of international banking. 
The rest of the paper is organized as follows. The next section presents the main theoretical hypotheses under scrutiny and the econometric methodology adopted. Section 3 describes the data used in the empirical analysis. Section 4 presents the results of the econometric analysis. The final section concludes.

\section{Empirical model}

\subsection{Choice of explanatory variables}

A major strength of our data set is that it allows us to study the pattern of bank internationalization controlling for the role of factors specific to the investing bank and to the country where its headquarters are located. In choosing these control variables we have followed Focarelli and Pozzolo (2001), where it is shown that banks with foreign shareholdings are on average larger, have a larger share of non-interest income and have headquarters in countries with an efficient banking market, measured by the average return on assets.

We measure the degree of economic integration between countries by the geographical distance and by the level of bilateral trade (computed as the ratio of sum of imports from and exports to a destination country and the total value of imports and exports of the origin country). We assume that information costs are lower within countries that share the same language. Further, we test whether in the euro area (the 11 countries now members of the EMU) bank cross-border expansion is more intense. Clearly, these last two factors are more likely to be relevant in the case of subsidiaries, which are specialized in offering retail services to local customers.

We measure regulatory restrictions with an index of the limitations on domestic banking activities. Moreover, as a proxy for implicit limitation to entry we consider the degree of bank concentration (measured by the market share of the 5 largest institutions). Further, we also control for the law and order tradition (La Porta et al., 1998); foreign banks are in fact likely to feel more secure about expanding in countries where enforcement of contracts is easier, since this favors the 
development of the banking system (Levine, 1998). Clearly, institutional aspects are more liable to be important in explaining the location of subsidiaries than of branches, as the former require a stronger presence in the foreign country.

Finally, we consider whether the country of destination hosts an international financial center, such as London, New York and Tokyo. Indeed, in particular within OECD countries, this characteristic cannot be considered strictly institutional, but it is instead primarily the outcome of historical factors. It is in any case likely to have a strong impact, especially for branches.

As we mentioned in the introduction, the literature on international banking considered total and per capita GDP as proxies for the level of profit opportunities in the foreign market. In our view, these measures have two main drawbacks. First, unitary bank profits are likely to be lower in more developed countries, where the banking sector is usually more competitive. Second, within a group of countries whose long-run rate of economic growth is likely to be converging to a common level, such as the OECD countries, poorer nations have higher expected rates of economic development than wealthier ones. For these reasons, we adopt a broader definition of local market opportunities: we assume that banks prefer to expand to countries where the expected rate of economic growth is higher and the banking system is on average less efficient. Following the results of the recent empirical literature on the determinants of growth, we then assume that countries with a lower level of initial output, lower inflation, higher levels of schooling and more developed financial markets are those more likely to have a faster rate of economic growth in the coming years. With respect to the size of the financial market we follow Levine and Zevros (1998), considering two proxies: the value of stock market capitalization and that of total credit, both measured as ratios to GDP.

Finally, we consider the role of the profitability and efficiency of the banking sector in the country of destination of the investment. In particular, among the explanatory variables we include the average levels of: free cash flow (equity net of fixed assets and loan loss reserves), cost-income ratio (overheads to total income), and return on assets. High levels of free cash flows might indicate an inefficient use of capital, possibly because of a lower ability in taking on investment opportunities; 
high cost-income ratios are associated with less cost efficient banking industries (although this could be due to the presence of highly skilled workers); and high return on assets characterizes more profitable banking markets, possibly due to a less competitive environment.

\subsection{Econometric setup}

The empirical analysis seeks to answer the following question: what are the characteristics of countries where banks are more likely to have a foreign branch or subsidiary? We model this as a set of binary choices that each bank makes on whether or not to operate a branch or a subsidiary in any one of the countries in our sample. In practice, we estimate

$$
\operatorname{Pr}\left(Y_{i j h}=k\right)=f\left(X_{i}, Z_{j}, B_{j h}, K_{h}\right), \quad k=0,1,2
$$

where: $Y_{i j h}=0$ when the bank $i$ of country $j$ has no foreign branches or subsidiaries in country $h, Y_{i j h}=$ 1 when the bank has a foreign branch but no subsidiaries, and $Y_{i j h}=2$ when the bank has a foreign subsidiary, irrespective of whether it has a branch or not; $X_{i}$ is a vector of bank-specific variables; $Z_{j}$ is a vector of country-specific variables; $B_{j h}$ is a vector of variables describing the relationship between the home country and the destination country and $K_{h}$ is a vector of variables specific to the destination country. The product of the number of banks in the sample times the number of possible countries of destination of the investment gives the number of observations used in the estimation.

We acknowledge that considering all banks with foreign subsidiaries as a single group, irrespective of whether they have a foreign branch in the same country, is somewhat arbitrary, even if the ownership of a subsidiary is an incontrovertible sign of a major interest of the bank in expanding its activities in that country. To check whether our results are sensitive to the chosen specification, we have also re-estimated the model allowing for an additional category when a bank has both a foreign branch and a foreign subsidiary in a given country (see, below, section 4.2). 


\section{Data and summary statistics}

\subsection{Data on banks}

Information on foreign branches are from The Bankers' Almanac. All other bank-specific data are from Bankscope, an international data set of balance-sheet items on individual banks, where all the main information on assets, liabilities and revenues is reported according to a common, comparable standard. Foreign subsidiaries are included in the sample as autonomous banks. As is common in the literature, we consider only the first level of foreign shareholdings. In order to minimize the effects of particular events, all data on banks' assets, liabilities and revenues are averages of annual values from 1994 to 1997. Information on branches and foreign shareholders refers to the end of 1998.

The first question is how to define foreign shareholdings. In principle, one would like to find a minimum percent equity interest needed to ensure the effective power in determining the bank's activity. Clearly, this depends on the distribution of ownership, so that the extreme case that a 50 per cent share is needed for an effective control might be too stringent. Thus, we took the opposite route, defining as foreign subsidiaries all banks with a shareholder out of the country, without any participation threshold. We acknowledge that this choice is somewhat questionable, and for this reason we will check the robustness of our results under the more stringent hypothesis that a majority equity interest is needed in order to gain operational control (see, below, section 4.2).

The data set includes 260 banks with total assets of more than $\$ 25$ billion and with headquarters in one of the 29 OECD countries (table 1). Japan has the largest number of banks in the sample (56); the United States have 42 banks, Germany 33; Italy, the United Kingdom and France have between 15 and 22 each; all the other countries have fewer than 10 . Of the 260 banks in the sample, 168 have foreign branches (65 per cent) and 114 have foreign subsidiaries (44 per cent); 30 have foreign shareholders (12 per cent). 
Table 2 reports the location of foreign branches of banks included in the sample. There are 683 instances of foreign branches, 9.4 per cent of the total number of possible foreign branches (given by the product of the number of banks, 260, times the number of possible countries of destination, 28). Japanese banks have the largest number of foreign branches (123), followed by those from the United States (96) and Germany (87). The United States host the largest number of foreign branches (117), closely followed by the United Kingdom (116). Japan, France, Germany and Italy host between 51 and 36 foreign branches. In the last column of table 2 we report the number of instances where a bank has a foreign branch in a country of destination without having a subsidiary. There are 102 instances of banks having both a branch and a subsidiary in the same country (1.4 per cent of the total number), nearly half of them are located in the United Kingdom (25) and in the United States (16), two major financial centers.

Table 3 reports that there are 299 cross-border shareholdings in the sample, or 4.1 per cent of the total number of possible foreign subsidiaries. German banks have the largest number of foreign subsidiaries (68), followed by Japan (39) and the United States (36). The largest number of banks with foreign shareholders is hosted by Luxembourg (47), followed by the United Kingdom (31), the United States (20), France and Germany (19). The last column of table 3 reports the number of instances where a bank has a foreign subsidiary in a country of destination without having also a branch. In total there are 197 of such cases, or 2.7 per cent of the total.

Table 4 reports some summary statistics for the 260 banks in the sample. Banks with crossborder interests are in general larger. However, banks that only have a foreign branch are smaller, have on average higher net interest margins and net charge-offs, lower levels of profitability, and cash flows. Banks with foreign subsidiaries have instead higher profitability and non-interest income, and lower interest margins. 


\subsection{Data on countries}

Data on GDP, population, bank credit and inflation are from IMF, International Financial Statistics (1998). Bilateral trade data are from IMF Direction of Trade Statistics (1998). Stock market capitalization is from IFC, Emerging Stock Markets Factbook (1998). Data on the "rule of law" are taken from La Porta et al. (1998). Data on the level of regulatory restrictions on domestic banking activity are taken from Barth et al. (2000). Finally "schooling" is the average schooling years in the total population in 1995; it is taken from Barro and Lee (2000). All the variables considered have a high degree of cross-country variability (table 5 ).

\section{Econometric results}

\subsection{Results from the basic model}

In the estimates, we exclude Luxembourg, Iceland, the Czech Republic, Hungary and Poland from our sample due to the lack of information on several variables. Multiplying the number of remaining banks (257) by the number of remaining countries (23) we obtain 5,911 paired bank-country observations. In the sample, there are 561 cases (9.5 per cent of all possible cases) of banks having a foreign branch in a country without having a subsidiary and 228 cases ( 3.9 per cent of all possible cases) of banks having a subsidiary, irrespective of whether or not they have also a branch in the destination country. The results of the estimation of equation (1) are reported in table 6.

The coefficients are estimated with respect to the baseline case of no foreign branches or subsidiaries. The test for the independence of irrelevant alternatives (IIA), verifying that the multinomial logit framework is to be preferred to two binomial logit regressions, was unable to reject the null hypothesis that the remaining alternative available to a bank is irrelevant: the multinomial logit seems correctly specified and provides consistent and efficient estimates of the coefficients. The Rsquared of the regression is 0.35 , a fairly good result for a cross-section analysis. 
Table 6 also reports the magnitude of the marginal effect of each explanatory variable. In the case of continuous variables this is measured as the change in the probability that a bank will have a branch or a subsidiary in a given country associated with a change in the covariate from the $25^{\text {th }}$ to the $75^{\text {th }}$ percentile of its sample distribution, leaving all other variables at their sample values. For dummy variables, the marginal effect is calculated as the change in the probability associated with a change of the variable from zero to one.

Some of the variables included in the empirical model describe complementary aspects of what can be identified as a unique factor affecting the pattern of bank internationalization. In order to make it easier to compare the effects of the different factors, we calculated the marginal effect of a set of synthetic variables defined as weighted averages of sets of regressors included in the basic specification. ${ }^{9}$ We have identified 5 factors describing respectively: attributes of the single bank and its country of origin, the degree of bilateral integration, institutional features of the country of destination, and the overall growth opportunities for the country of destination, separating the growth prospects of the whole economy from the characteristics of its banking sector.

\subsubsection{Characteristics of the bank and of the country of origin}

Characteristics of the bank and of the country of origin are introduced in the estimation mainly as control variables. The attributes of banks with foreign equity interests are studied in more detail in Focarelli and Pozzolo (2001).

The size of the bank is a key determinant of the decision to expand abroad. Larger banks are more likely to have both foreign branches and foreign subsidiaries. Similarly, banks with a larger share of non-interest income are more likely to have foreign activities, probably because they have more innovative and aggressive strategies both at home and abroad. ${ }^{10}$ Banks in countries where the banking sector is more profitable are also more likely to expand abroad, consistent with the hypothesis that they are specialized in the supply of more advanced services which are typically more lucrative. Overall, the factor describing the characteristics of the bank and of the country of origin has more than double the 
marginal effect in the case of branches (11.4 per cent) than in the case of subsidiaries (5.1 per cent); normalizing with the level of the predicted probabilities they have approximately the same size.

\subsubsection{Economic integration between countries}

The coefficient of bilateral trade is positive and significant for both branches and subsidiaries. In both cases the effect of increasing the share of bilateral trade between the two countries from the $25^{\text {th }}$ to the $75^{\text {th }}$ percentile is very small.

The coefficient of the dummy variable taking the value of one for country pairs where the same language is spoken is negative but not significantly different from zero in the case of branches. It is positive but not significantly different from zero in the case of subsidiaries. However, the difference between the two coefficients is significant at the 5 per cent level, possibly because banks consider easier to control the activities of the foreign subsidiary in countries where a common language is spoken. ${ }^{11}$ The probability that a bank will have a foreign subsidiary in a country where the same language is spoken is 1.6 per cent higher than average.

The coefficient of the geographical distance is negative and significant for both branches and subsidiaries, showing that banks are less likely to have foreign interests in countries far away. Consistent with previous results, the marginal effect is 1.5 per cent for branches and 1.2 for subsidiaries. After normalization it is therefore larger for the latter.

As it is shown in the rich literature on gravity models of trade, it could be the case that these three variables are highly collinear, especially when per capita GDP of the country of destination is also included in the regression. However, our results are robust to the exclusion of each one of these variables. $^{12}$

Finally, the positive coefficients of the dummy variables for the countries that eventually joined the European Monetary Union confirm that the prospect of a common monetary market and the absence of exchange rate risk resulted in an increase in the number of foreign branches and subsidiaries. Consistent with the interpretation of the dummy for countries where a common language 
is spoken, the coefficient is larger in the case of subsidiaries, and the difference with that for branches is highly significant. The probability that a bank will have a cross-border interest in a country that eventually joined the European Monetary Union is 2.5 per cent higher than average in the case of branches, 4.9 per cent in the case of subsidiaries. The difference is much larger when the effects are normalized with the predicted probabilities.

Overall, the factor describing the effect of the degree of integration between countries has a stronger marginal effect for branches ( 3.0 per cent) than for subsidiaries ( 1.5 per cent), but this result is reversed if normalized with respect to the predicted probability. This result is mainly driven by the effect of the dummy for countries that eventually joined the EMU.

\subsubsection{Institutional characteristics}

The results of table 6 show that implicit and explicit institutional barriers play a crucial role in the pattern of bank internationalization. This finding, common in the literature, is confirmed and reinforced in our analysis.

The coefficient of the level of restrictions on banking activities is not significantly different from zero in the case of branches, but it is negative and significant for subsidiaries (the difference between the two is highly significant). This result is not obvious. In fact, some authors have suggested that banks prefer to invest in more regulated and protected markets, possibly because they expect to obtain higher profits because markets are less competitive. By contrast, other authors have suggested that, even when explicit legislative limitations are not present, heavily regulated banking systems are typically less accessible to foreign banks. This latter interpretation is in line with our results, which are reinforced if one considers that regulation is likely to be less binding for branches than for subsidiaries. A change of the level of restrictions from the $25^{\text {th }}$ to the $75^{\text {th }}$ percentile reduces the probability that a country hosts foreign subsidiaries by 1.3 per cent.

The concentration of the banking sector, an indirect measure of the accessibility of the market for both residents and non-residents, also affects the probability that a country hosts foreign banks. The 
coefficients for branches and subsidiaries are both significantly different from zero, but the latter is significantly larger. The marginal effect in both cases is sizeable, between 4 and 5 per cent. After normalization it is much larger for subsidiaries, as is to be expected given that they are more likely than branches to compete with local banks.

The presence of a stronger law and order tradition in the country (the "rule of law") increases the probability that it will host foreign banks. As expected, this only happens for subsidiaries, which typically have a larger involvement with activities regulated by local laws. An increase in the measure of law and order tradition from the $25^{\text {th }}$ to the $75^{\text {th }}$ percentile augments the probability that a country hosts a foreign subsidiary by 2.6 per cent.

The presence of a financial center is also a major factor affecting the probability that a country hosts foreign banks, but only in the case of branches. This result is not surprising as most foreign branches operate in wholesale markets, such as the financial markets. Indeed, the marginal effect of the dummy for the three financial centers in our sample (London, New York and Tokyo) is the largest of all, increasing the probability of a bank opening a foreign branch in that country by 15.6 per cent.

As we claimed at the start, institutional factors play a pivotal role in determining the pattern of banks' international expansion; the factor has indeed a strong marginal effect. In absolute terms it is larger for branches (6.5 per cent) than for subsidiaries ( 2.7 per cent); but as to the value of predicted probabilities they are quite similar.

\subsubsection{Profit opportunities}

The results presented in table 6 provide strong evidence that profit opportunities in the destination country are another key factor affecting the pattern of banks' international expansion.

In our analysis we have divided the variables describing profit opportunities into two major groups: those related to the general prospects of growth of the hosting country, and those describing the characteristics of its banking sector. Within the first group we have considered per capita GDP, the level of inflation, the level of schooling, and the size of the banking sector. We interpreted the latter 
variable as a proxy of the financial development of the country and therefore included it among the factors describing its general prospects of growth because of its relation with the ratio of stock market capitalization over GDP. Indeed, we obtained similar results to those presented in table 6 substituting credit size with stock market capitalization. ${ }^{13}$

The coefficients of the variables describing the country's growth prospects are significant in all but one case (inflation in the regression for subsidiaries). In particular, per capita GDP and schooling (the two variables most commonly included in the growth regressions) are significantly larger in absolute size for subsidiaries than for branches, a result that is consistent with the stronger involvement of subsidiaries in the local economy.

Overall the marginal effects of a change from the $75^{\text {th }}$ to the $25^{\text {th }}$ percentile of the value of the factor describing the effect of country growth opportunities is 3.4 per cent for branches, 2.2 per cent for subsidiaries; therefore, normalizing with respect to predicted probabilities it is much larger for the latter.

Turning to variables describing the efficiency of the banking sector in the destination country, the research on banking consolidation at domestic level has shown that in a substantial share of mergers and acquisitions, larger and more efficient institutions tend to take over smaller, less efficient firms, possibly to spread their expertise and operating procedures over additional resources (see, for example, Berger et al., 1999; Focarelli et al., 2002). Consistent with this hypothesis, our evidence shows that foreign banks are more likely to establish branches and subsidiaries in countries where banks have on average higher cash flow, higher costs, and higher profitability. Indeed, high cash flow is likely to be due to an inefficient use of equity capital; more efficient investors coming from abroad might then be in the position to have a better than average capital structure, and therefore to have higher profits. Besides, the effect is significantly larger for subsidiaries. The positive sign of the coefficient of costs is similarly consistent with the view that foreign investors can gain extra profits when operating in less efficient markets. Finally, after controlling for inefficiency, we also find that 
foreign banks are more likely to be present in countries where profitability is higher, consistent with the view that profit opportunities are a key determinant of the pattern of cross-border expansion.

In the case of branches, the factor describing the effect of the characteristics of the host-country banking sector has a marginal effect of 3.1 per cent, similar to that describing the country's general growth prospects. In the case of subsidiaries the marginal effect is also equal to 3.1 per cent, a large value compared with both the other four factors and the average predicted probability.

\subsection{Robustness checks}

We tested for the robustness of the results reported in table 6 in a number of ways. First, we adopted different estimation techniques. The results reported in panel A of table 7 show that the sign and the significance of the coefficients are not different from those of our preferred specification, even estimating equation (1) with fixed effects for the individual banks, the origin country, and the destination country. The only minor exception is the coefficient of the dummy for common language, which becomes significant for subsidiaries when either the individual-bank or the origin-country fixed effects are included in the regression.

Second, in order to control for the role of extreme values, we estimated equation (1) on each subsample obtained after dropping recursively one destination country from our original sample and calculated a jackknife estimator as the mean of the 24 estimates. The results show that our basic estimates are not driven by some extreme values taken by variables describing the destination-country characteristics. Indeed, the estimates reported in panel B of table 7 are similar to those in table 6 , and minima and maxima are not too far apart from mean values.

Third, in an unreported regression we estimated a multinomial logit specification allowing for 4 categories: (i) no presence abroad, (ii) only a foreign branch, (iii) only a foreign subsidiary and (iv) both a foreign branch and a foreign subsidiary. ${ }^{14} \mathrm{We}$ found only three variables with statistically and economically different coefficients in cases (iii) and (iv): language, financial center and rule of law. ${ }^{15}$ The coefficient of the dummy variable taking the value of one for country pairs where the same 
language is spoken is positive and significantly different from zero when banks have in a given foreign country only a subsidiary, while it is negative and not significantly different from zero when they have both a branch and a subsidiary. The coefficient of the dummy for financial centers is negative when banks have in a given foreign country only a subsidiary and positive when they have both a branch and a subsidiary; in both cases, the coefficients are significantly different from zero. The coefficient of rule of law is positive and significantly different from zero when banks have in a given foreign country only a subsidiary, while it is negative and not significantly different from zero when they have both a branch and a subsidiary. If anything, these results strengthen the interpretation given to previous results that: i) sharing the same language only matters in the case of foreign subsidiaries; ii) financial centers attract branches of foreign banks, but not subsidiaries; iii) countries with a stronger law and order tradition, which proxies for the ability of the legal system to enforce contracts, are more likely to host foreign subsidiaries (while they are less likely to host foreign branches).

Finally, we ran a supplementary unreported regression in which foreign subsidiaries were defined as banks where out of the country shareholders hold at least the 50 per cent of total equities, which also corroborated our previous results. Indeed, despite a reduction in the number of foreign subsidiaries from 228 to 154 , the only difference that we found relates to the coefficients of distance, cost-income and return on assets in the destination country for the case of subsidiaries, which turn out being not significantly different from zero, although they maintain the same sign and a similar size as those reported in table 6.

\section{Conclusions}

Our analysis of the pattern of banks' foreign investment, based on a sample of 260 large banks from OECD countries, shows that the degree of integration between the home country and the destination country has a positive effect on the probability that a bank will expand in a given country, consistent with previous research. However, it also shows that the marginal effect of integration is much lower than that of other explanatory factors, such as institutional characteristics and profit opportunities. 
In particular, profit opportunities appear to be a key factor affecting the pattern of banks' international expansion. The importance of lower per capita GDP, lower inflation, and larger credit market assigns a prominent role to the expected growth of the destination country. The positive correlation between the presence of foreign banks and high costs and a less efficient use of equity capital makes plausible the view that foreign investors gain profits when competing with less efficient banks. The marginal effect of these variables is relatively larger for subsidiaries, suggesting that the profitability of foreign branching is less dependent on the prospect of growth of the local economy.

Institutional characteristics of the destination country also play a crucial role in the pattern of bank internationalization. For these variables the separation between branches and subsidiaries turns out to be extremely informative.

On the one hand, we find that financial centers attract branches of foreign banks, but not subsidiaries. On the other hand, we find that banks prefer to acquire equity interests in countries where either regulatory restrictions on banking activities are lower or the market is less concentrated, possibly because these variables are proxies of actual, sometimes hidden, limitations to entry from abroad. Regulatory restrictions have no effects on the decision about where to open a branch. Further, countries with a stronger law and order tradition, which proxies for the ability of the legal system to enforce contracts, are more likely to host foreign subsidiaries.

A richer theory, possibly grounded on the search for profits in the presence of barriers to entry in foreign markets, seems more suitable than the "follow the client" hypothesis to explain the pattern of bank internationalization.

The entry of foreign banks in the domestic market has traditionally been a matter of concern for policymakers, because they are far more complicated to supervise (see Dale, 1984) and may enhance the financial fragility of the destination country by failing to continue operating when a worsening of the economic environment squeezes their profitability or increases their risk. ${ }^{16}$ Our results indirectly suggest a more positive interpretation of foreign banking activities. Foreign banks may indeed have a positive effect on the average efficiency of the banking sector in the destination country, because they 
are likely to be among the most efficient in their country of origin, to come from the most developed banking markets and to be located in less efficient banking sectors.

\section{References}

Ball, C. A. and A. E. Tschoegl (1982), "The Decision to Establish a Foreign Branch or Subsidiary: An Application of Binary Classification Procedures", Journal of Financial and Quantitative Analysis, 17, 411-24.

Barro, R. J. and J. Lee (2000), "International Data on Educational Attainment: Updates and Implications", Harvard University, mimeo.

Barth, J. R., G. Caprio Jr., R. Levine (2000), "Banking Systems Around the Globe: Do Regulation and Ownership Affect Performance and Stability?”, Working Papers - Domestic Finance No. 2325, World Bank

Berger A. N., R. S. Demsetz, P. E. Strahan (1999), "The Consolidation of the Financial Services Industry: Causes, Consequences, and Implications for the Future”, Journal of Banking and Finance, 23, pp.135-194.

Berger, A. N., R. DeYoung, H. Genay, and G. F. Udell (2000), "The Globalization of Financial Institutions: Evidence from a Cross-Border Banking Performance”, Brookings-Wharton Paper on Financial Service 2000, 23-120.

Berger, A. N.,A. K. Kashyap and J. M. Scalise (1995), “The Transformation of the U. S. Banking Industry: What a Long, Strange Trip It's Been”, Brookings Papers on Economic Activities, 2, pp. 55-218.

Boot, A. W. A. (1999), "European Lessons on Consolidation in Banking", Journal of Banking and Finance, 23, pp. 609-613.

Brealey, R. A. and E. C. Kaplanis (1996), “The Determination of Foreign Banking Location”, Journal of International Money and Finance, 15, pp. 577-97. 
Buch, C. M. (2000), "Why Do Banks Go Abroad? Evidence from German Data”, Journal of Financial Markets, Instruments and Institutions, 9, pp. 33-67.

Buch , C. M. (2002), "Information or Regulation: What is Driving the International Activities of Commercial Banks?", Journal of Money Credit and Banking, forthcoming.

Claessens, S., A. Demirgüç-Kunt, and H. Huizinga (2000), “The Role of Foreign Banks in Domestic Banking Systems", in S. Claessens and M. Jansen, (eds.), The Internationalization of Financial Services: Issues and Lessons for Developing Countries, Boston, MA, Kluwer Academic Press.

Dale, R. (1984), The Regulation of International Banking, Cambridge, Woodhead Faulkner.

Fisher, A., and P. Molyneux (1996), “A Note on the Determinants of Foreign Bank Activity in London Between 1980 and 1989”, Applied Financial Economics, 6, pp. 271-277.

Focarelli, D., F. Panetta and C. Salleo (2002), “Why Do Banks Merge?”, Journal of Money Credit and Banking, Vol. 34, No. 3 (August, Part 1), pp. 784-803.

Focarelli, D. and A. F. Pozzolo (2001), "The Patterns of Cross-Border Bank Mergers and Shareholdings in OECD Countries", Journal of Banking and Finance, 25, pp. 2305-2337.

Goldberg, L. G. and R. Grosse (1994), "Location Choice of Foreign Banks in the United States", Journal of Economics and Business, 46, pp. 367-79.

Goldberg, L. G. and D. Johnson (1990), “The Determinants of U.S. Banking Activity Abroad”, Journal of International Money and Finance, 9, pp. 123-37.

Goldberg. L. G. and A. Saunders (1980), "The Causes of U.S. Bank Expansion Overseas: The Case of Great Britain”, Journal of Money Credit and Banking, 12, pp. 630-43.

Goldberg. L. G. and A. Saunders (1981), “The Growth and Organizational Form of Foreign Banks in the U. S.”, Journal of Money Credit and Banking, 13, pp. 365-74.

Grosse, R. and L. G. Goldberg (1991), "Foreign Bank Activity in the United States: an Analysis by Country of Origin”, Journal of Banking and Finance, 15, pp. 1092-112. 
Group of Ten (2001), "Consolidation in the Financial Sector - Summary Report", available at the web sites of the BIS, the IMF, the OECD, the Bank of Italy.

Hausman, J. A. and D. L. McFadden (1984), "Specification Tests for the Multinomial Logit Model", Econometrica, 52, pp. 1219-1240.

IFC (1998), Emerging Stock Markets Factbook.

IMF (1998), International Financial Statistics Yearbook.

IMF (1998), Direction of Trade Statistics.

Kroszner, Randall S. (1999), "Is the Financial System Politically Independent? Perspectives on the Political Economy of Banking and Financial Regulation", University of Chicago, mimeo.

La Porta, R., F. Lopez-de-Silanes, A. Shleifer and R. W. Vishny (1998), “Law and Finance”, Journal of Political Economy, 106, pp. 1113-1155.

Levine, R. (1998), “The Legal Environment, Banks, and Long-Run Economic Growth”, Journal of Money Credit and Banking, 30, pp. 596-613.

Levine, R., and S. Zevros (1998), "Stock Markets, Banks, and Growth", The American Economic Review, Vol. 88, No. 3, pp. 537-58.

Miller, S.R., and A. Parkhe (1998), "Patterns in the Expansion of U.S. Banks' Foreign Operations", Journal of International Business Studies, 29, pp. 359-390.

Nigh, D., K.R. Cho, and S. Krishnan (1986), "The Role of Location-Related Factors in U.S. Banking Involvement Abroad: An Empirical Analysis”, Journal of International Business Studies, pp. $59-72$.

Peek, J. and E. S Rosengren (1997), “The International Transmission of Financial Shocks: the Case of Japan”, American Economic Review, 87, pp. 495-505.

Rajan, R. G. (1998), “The Past and Future of Commercial Banking Viewed through an Incomplete Contract Lens", Journal of Money Credit and Banking, 30, pp. 524-50.

Sagari, S. B. (1992), “United States Foreign Direct Investment in the Banking Industry”, Transnational Corporations, pp. 93-123. 
Tschoegl, A. E. (1982), “Concentration among International Banks”, Journal of Banking and Finance, 6, pp. 567-78.

Tschoegl, A. E. (1983), "Size, Growth, and Transnationality among the World's Largest Banks", Journal of Business, pp. 187-201.

Ursacki, T. and I. Vertinsky (1992), "Choice of Entry Timing and Scale by Foreign Banks in Japan and Korea”, Journal of Banking and Finance, 16, pp. 405-21.

ter Wengel (1995), "International Trade in Banking Services", Journal of International Money and Finance, 14, pp. 47-64.

Williams, B. (1996), "Determinants of the Performance of Japanese Financial Institutions in Australia 1987-1992”, Applied Economics, 28, pp. 1153- 65.

Williams, B. (1998), "Factors Affecting the Performance of Foreign-Owned Banks in Australia: a Cross-Sectional Study", Journal of Banking and Finance, 22, pp. 197-219.

Yamori, N. (1998), "A Note on the Location Choice of Multinational Banks: the Case of Japanese Financial Institutions", Journal of Banking and Finance, 22, pp. 109-20.

\section{FOOTNOTES}

${ }^{1}$ For a more detailed analysis of the organizational structures available to a bank wishing to expand its activities abroad see Goldberg and Saunders (1981).

${ }^{2}$ For example, the 323 foreign branches operating in New York at the end of 1985, 5 times more than in 1971, declined to 205 by 1998 .

${ }^{3}$ The degree of economic integration between home and destination countries has been measured in the literature by at least three variables: geographical distance (Ball and Tschoegl, 1982; Grosse and Goldberg, 1991); the volume of bilateral trade flows (Goldberg and Saunders, 1980 and 1981; Goldberg and Johnson, 1990; Grosse and Goldberg, 1991; Brealey and Kaplanis, 1996; Yamori, 1998); and the value of bilateral foreign direct investment (Nigh, et al., 1986; Goldberg and Johnson, 1990; Grosse and Goldberg, 1991; ter Wengel, 1995; Sagari, 1992; Brealey and Kaplanis, 1996; Williams, 1998; Yamori, 1998; Miller and Parkhe, 1998; Buch, 2000). Cultural characteristics have been considered by Buch (2002), who finds that language is important in explaining 
the degree of internationalization of Spanish banks, whereas it is not significant for the banks of other EU countries.

${ }^{4}$ A number of studies (e.g., Nigh et al., 1986; Goldberg and Johnson, 1990; Sagari, 1992; Miller and Parkhe, 1998) find that restrictions on the entry of foreign investors significantly reduce the degree of internationalization of a country's banking market. A related result is that US banks prefer to expand in countries where capital requirements are less stringent and taxes are lower (Miller and Parkhe, 1998). Kroszner (1999) suggests that actions to permit more cross-border activities might indeed reflect an increased strength of interest groups that benefit from technological innovations and globalization of financial services.

${ }^{5}$ Indeed, the causality of these relationships must be interpreted with caution. For example, if foreign investors can influence the political decision process (e.g., in favor of less restrictive regulations), regulations could be in part endogenous with respect to the presence of foreign banks. Similar, the presence of foreign banks might help reducing the concentration in the banking industry (for a closely related issue, see Tschoegl; 1982).

${ }^{6}$ A positive correlation between the size of banks and their degree of internationalization has been found in a number of empirical studies: Ball and Tschoegl (1982), Tschoegl (1983), Ursacki and Vertinsky (1992), Williams (1996 and 1998).

${ }^{7}$ Grosse and Goldberg (1991) find a positive correlation between the number of foreign banks in the United States from a given country and the development of that country's financial sector.

${ }^{8}$ For example, Brealey and Kaplanis (1996) show that parent banks use foreign branches mainly to operate in the leading financial centers and to support the activities abroad of their home-country clients. Indeed, these two activities are less likely to be the driving forces for the acquisition of foreign subsidiaries, which are normally used by banks to offer retail services abroad.

${ }^{9}$ The weights used in order to calculate the synthetic variables (factors) are given by the coefficients of the regressors included in the factor in two independent binomial logit regressions estimating separately the probability of a bank having a foreign branch and a foreign subsidiary (these estimates are consistent, although inefficient). By construction, the coefficients of the factors in the multinomial logit regression are all about one. Table 6 reports the marginal effects associated with a change in each factor from its level at the $25^{\text {th }}$ to that at the $75^{\text {th }}$ percentile in the sample distribution, leaving all other factors at their sample values. 
${ }^{10}$ One possibility is that banks with foreign interests are larger and have a larger share of non-interest income precisely because they have expanded abroad, i.e., that there is a causality issue to consider. We have excluded this interpretation after finding, in an unreported regression, that in our sample banks with cross-border interests did not experience a higher than average rate of growth of total assets and did not augment their share of non-interest income.

${ }^{11}$ This interpretation is also strengthened by the results of the robustness checks discussed in section 4.2 below, showing that the dummy for common language becomes positive and significant for subsidiaries when either the individual-bank or the origin-country fixed effects are included in the regression and when an alternative multinomial logit specification is adopted, which allows for an additional category when a bank has both a foreign branch and a foreign subsidiary in a given country.

${ }^{12}$ In some unreported regressions we have also considered the value of bilateral foreign direct investment, obtaining similar results. We preferred to measure trade integration because data are available for a larger number of countries.

13 Including both variables at the same time only had the effect of reducing the significance of the two estimated coefficients, without changing their sign.

${ }^{14}$ We preferred to present the results of the multinomial logit specification with 3 categories because it delivers more concisely the same message as the 4 categories model.

${ }^{15}$ Also the coefficients of the bank size and of the average return on assets in the banking sector of the country of origin in the two cases were significantly different from each other, but the differences were not economically meaningful.

${ }^{16}$ Moreover, it is believed that they are excessively sensitive to economic conditions in the home country of the parent company. Peek and Rosengren (1997) actually found that lending by Japanese banks in the US declined as a result of the stock market crash in Japan. 
Table 1

\section{Bank's Distribution by Size and Country}

Source: Bankscope and The Banker's Almanac. Panel A refers to the banks with total assets of more than $\$ 25$ billion at December 1997 surveyed by Bankscope. Panel B includes 2,148 banks with headquarters in an OECD country and total assets of more than $\$ 1$ billion at December 1997 (from the 2,449 banks surveyed by Bankscope, 301 banks are excluded since they have either negative net interest margins, or negative non-interest income, or net return on assets lower than -1.0 per cent or higher than 4.0 per cent, or overheads higher than total operating income).

\begin{tabular}{|c|c|c|c|c|c|c|}
\hline \multirow[t]{2}{*}{ Country } & \multicolumn{4}{|c|}{$\begin{array}{c}\text { Panel A: } \\
\text { Banks with total assets } \\
\text { of more than } \$ 25 \text { billion }\end{array}$} & \multicolumn{2}{|c|}{$\begin{array}{c}\text { Panel B: } \\
\text { Potential targets }\end{array}$} \\
\hline & Total & $\begin{array}{l}\text { with } \\
\text { foreign } \\
\text { share- } \\
\text { holders }\end{array}$ & $\begin{array}{l}\text { with } \\
\text { foreign } \\
\text { branches }\end{array}$ & $\begin{array}{l}\text { with } \\
\text { foreign } \\
\text { subsidi- } \\
\text { aries }\end{array}$ & Total & $\begin{array}{l}\text { with } \\
\text { foreign } \\
\text { share- } \\
\text { holders }\end{array}$ \\
\hline Australia & 4 & 0 & 4 & 3 & 42 & 10 \\
\hline Austria & 3 & 2 & 3 & 3 & 41 & 8 \\
\hline Belgium & 6 & 1 & 4 & 5 & 27 & 7 \\
\hline Canada & 7 & 0 & 6 & 4 & 23 & 9 \\
\hline South Korea & 9 & 2 & 8 & 0 & 36 & 10 \\
\hline Denmark & 4 & 1 & 3 & 2 & 14 & 2 \\
\hline Finland & 3 & 0 & 2 & 0 & 7 & 1 \\
\hline France & 20 & 1 & 9 & 12 & 178 & 11 \\
\hline Germany & 33 & 3 & 24 & 26 & 472 & 19 \\
\hline Japan & 56 & 5 & 46 & 14 & 159 & 6 \\
\hline Greece & 1 & 0 & 1 & 1 & 12 & 1 \\
\hline Ireland & 2 & 0 & 1 & 2 & 23 & 9 \\
\hline Iceland & 0 & 0 & 0 & 0 & 2 & 0 \\
\hline Italy & 15 & 5 & 12 & 7 & 138 & 13 \\
\hline Luxembourg & 3 & 2 & 2 & 0 & 56 & 46 \\
\hline Mexico & 3 & 0 & 3 & 0 & 12 & 1 \\
\hline Norway & 1 & 1 & 1 & 0 & 21 & 10 \\
\hline New Zealand & 0 & 0 & 0 & 0 & 9 & 6 \\
\hline Netherlands & 5 & 0 & 3 & 3 & 31 & 8 \\
\hline Poland & 0 & 0 & 0 & 0 & 16 & 10 \\
\hline Portugal & 3 & 1 & 2 & 2 & 26 & 8 \\
\hline United Kingdom & 22 & 2 & 9 & 8 & 119 & 29 \\
\hline Czech Republic & 0 & 0 & 0 & 0 & 10 & 6 \\
\hline Spain & 8 & 3 & 5 & 4 & 94 & 12 \\
\hline United States & 42 & 1 & 15 & 14 & 488 & 18 \\
\hline Sweden & 5 & 0 & 2 & 2 & 14 & 1 \\
\hline Switzerland & 5 & 0 & 3 & 2 & 62 & 11 \\
\hline Turkey & 0 & 0 & 0 & 0 & 9 & 0 \\
\hline Hungary & 0 & 0 & 0 & 0 & 7 & 4 \\
\hline Total & 260 & 30 & 168 & 114 & 2148 & 276 \\
\hline
\end{tabular}




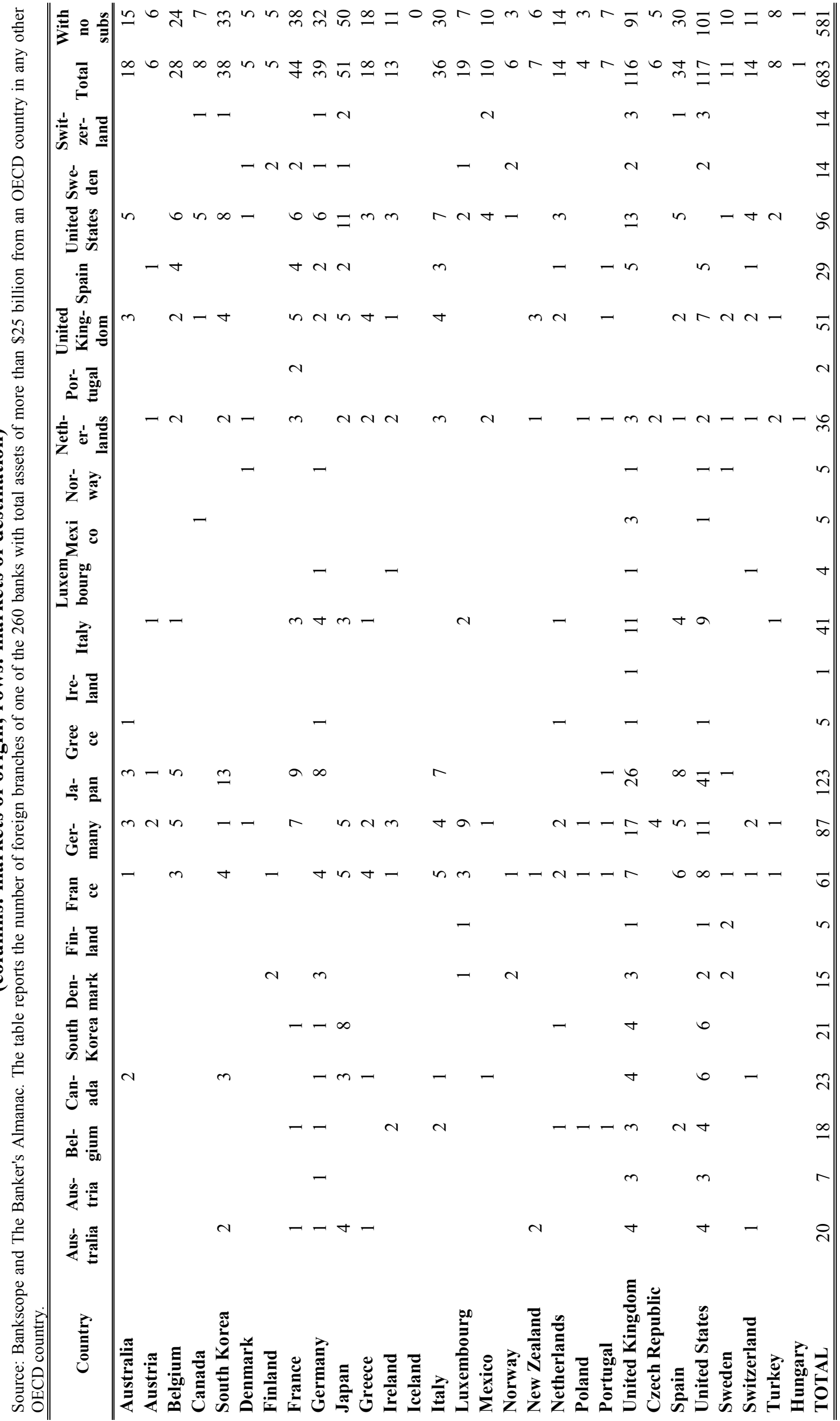


$\stackrel{\frac{3}{3}}{\frac{3}{4}}$

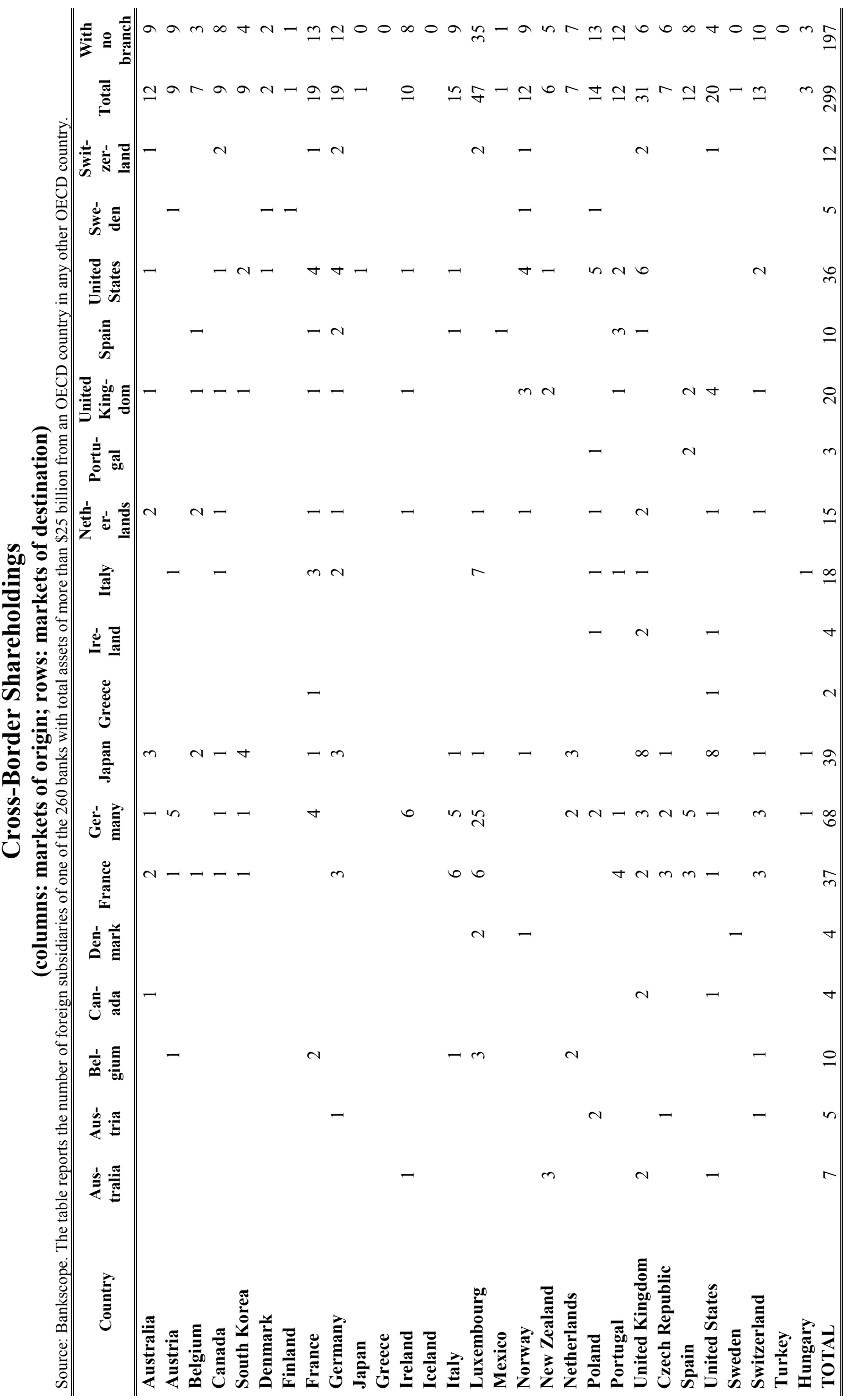




\section{Descriptive Statistics}

Panel A refers to banks in the sample with assets of more than $\$ 25$ billion. Panel B refers to banks with at least one foreign branch. Panel $\mathrm{C}$ refers to banks with at least one foreign subsidiary. Total assets are expressed in billions of US dollars. ROE is defined as income after tax in proportion to equity. ROA (income after tax), net interest margin, cash-flow (equity minus fixed assets and loan loss reserves) and net charge-offs are expressed as percentage ratios of total assets. Non-interest income is expressed as a percentage ratio of the sum of net interest margin and non-interest income. All data are calculated as the average value of 1994-1997 figures.
Variables
Obs.
Median Mean
Std.
Min.
Max.

Dev.

\begin{tabular}{|c|c|c|c|c|c|c|}
\hline \multicolumn{7}{|c|}{ Panel A: } \\
\hline \multicolumn{7}{|c|}{ Banks with total assets of more than $\$ 25$ billion } \\
\hline Total Assets & 260 & 57.93 & 105.93 & 113.12 & 25.08 & 715.45 \\
\hline Net ROE & 260 & 7.61 & 7.57 & 8.40 & -20.95 & 31.92 \\
\hline Net ROA & 260 & 0.28 & 0.41 & 0.50 & -0.85 & 2.27 \\
\hline Net Interest Margin & 259 & 1.63 & 1.75 & 1.02 & 0.09 & 5.07 \\
\hline Non-Interest Income & 260 & 32.08 & 33.71 & 20.98 & 0.47 & 100.00 \\
\hline Cash Flow & 260 & 2.74 & 3.36 & 2.95 & -1.21 & 31.10 \\
\hline Overheads & 260 & 65.11 & 63.55 & 15.20 & 14.91 & 98.61 \\
\hline Net Charge-offs & 260 & 0.22 & 0.31 & 0.37 & -0.94 & 2.15 \\
\hline \multicolumn{7}{|c|}{ Panel B: } \\
\hline \multicolumn{7}{|c|}{ Banks with foreign branches } \\
\hline Total Assets & 168 & 71.39 & 123.62 & 15966.45 & 25.71 & 715.45 \\
\hline Net ROE & 168 & 5.76 & 6.04 & 69.30 & -20.95 & 27.30 \\
\hline Net ROA & 168 & 0.22 & 0.31 & 0.19 & -0.62 & 1.54 \\
\hline Net Interest Margin & 168 & 1.65 & 1.76 & 0.71 & 0.13 & 4.63 \\
\hline Non-Interest Income & 168 & 33.51 & 33.50 & 279.30 & 1.08 & 91.84 \\
\hline Cash Flow & 168 & 2.37 & 2.63 & 2.90 & -1.21 & 7.81 \\
\hline Overheads & 168 & 65.50 & 65.64 & 136.66 & 26.64 & 94.27 \\
\hline Net Charge-offs & 168 & 0.30 & 0.39 & 0.16 & -0.94 & 2.15 \\
\hline \multicolumn{7}{|c|}{ of which: Banks with foreign branches and with no foreign subsidiaries } \\
\hline Total Assets & 76 & 44.96 & 65.74 & 3930.12 & 25.71 & 422.48 \\
\hline Net ROE & 76 & 3.67 & 4.07 & 69.94 & -20.95 & 23.59 \\
\hline Net ROA & 76 & 0.15 & 0.25 & 0.19 & -0.62 & 1.54 \\
\hline Net Interest Margin & 76 & 1.75 & 1.84 & 0.71 & 0.34 & 4.63 \\
\hline Non-Interest Income & 76 & 32.44 & 29.92 & 287.98 & 1.08 & 69.44 \\
\hline Cash Flow & 76 & 2.17 & 2.48 & 3.64 & -1.21 & 7.81 \\
\hline Overheads & 76 & 65.23 & 65.84 & 112.86 & 27.22 & 90.04 \\
\hline Net Charge-offs & 76 & 0.32 & 0.47 & 0.21 & -0.17 & 2.15 \\
\hline \multicolumn{7}{|c|}{ Panel C: } \\
\hline \multicolumn{7}{|c|}{ Banks with foreign subsidiaries } \\
\hline Total Assets & 114 & 110.91 & 159.44 & 19287.31 & 28.25 & 715.45 \\
\hline Net ROE & 114 & 8.01 & 8.08 & 64.69 & -15.19 & 29.73 \\
\hline Net ROA & 114 & 0.30 & 0.38 & 0.21 & -0.85 & 1.77 \\
\hline Net Interest Margin & 114 & 1.45 & 1.62 & 0.75 & 0.13 & 3.92 \\
\hline Non-Interest Income & 114 & 35.26 & 38.18 & 370.87 & 4.12 & 91.84 \\
\hline Cash Flow & 114 & 2.68 & 3.18 & 5.07 & -0.68 & 14.09 \\
\hline Overheads & 114 & 65.95 & 65.46 & 179.65 & 26.64 & 98.61 \\
\hline Net Charge-offs & 114 & 0.23 & 0.30 & 0.10 & -0.94 & 1.33 \\
\hline
\end{tabular}


留

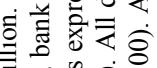

ㅎํㅇㅇㅇ

弪豞守过

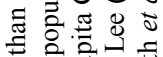

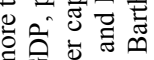
छी 仓े

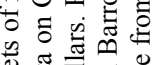

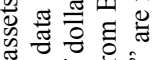

ฐँ

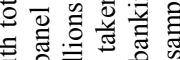

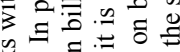

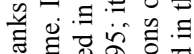

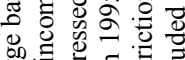

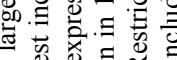

8 눙.

ฐ

용

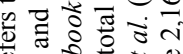

๑ี

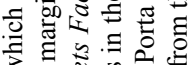

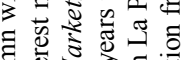

\& \& \& \& $\%$ \&

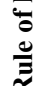

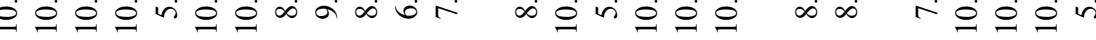

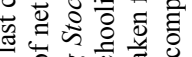

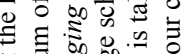

पे के

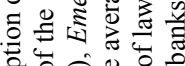

究

×

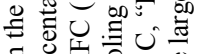

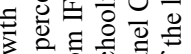

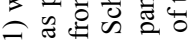

记.

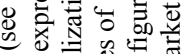

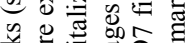

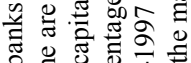

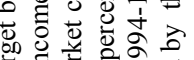

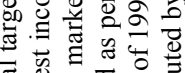

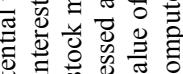

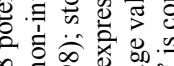

․ㅠ

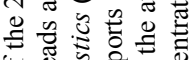

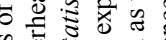

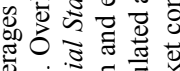

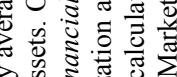

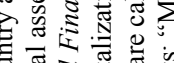

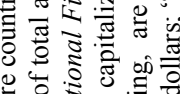

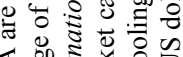

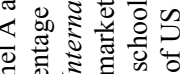

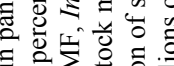

$\Xi$ ¿

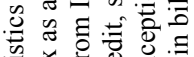

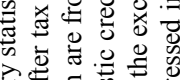

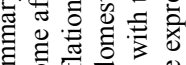

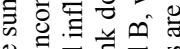

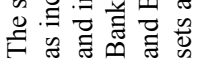

皇

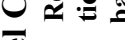

ฮ

च

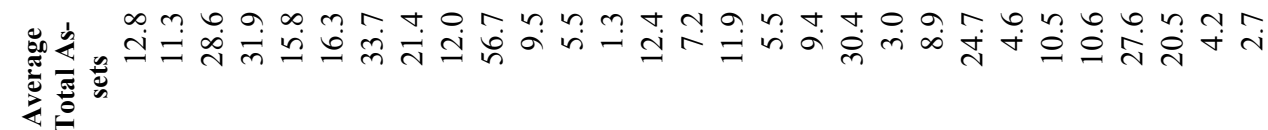

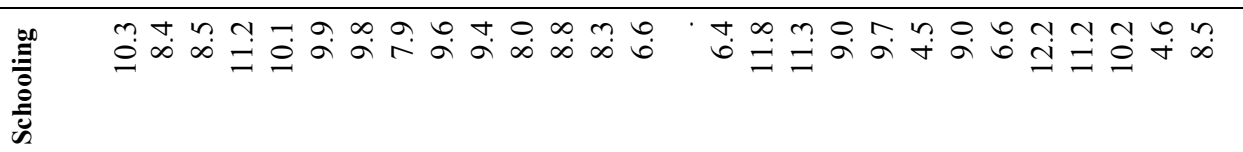

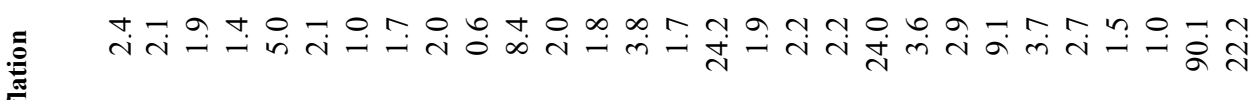

吾

ص

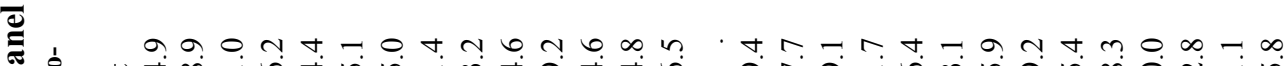

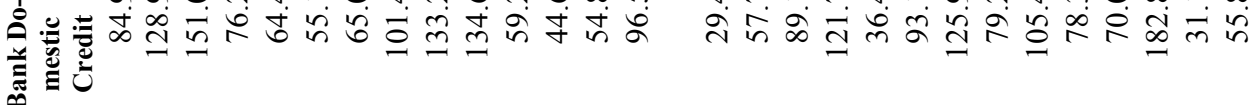

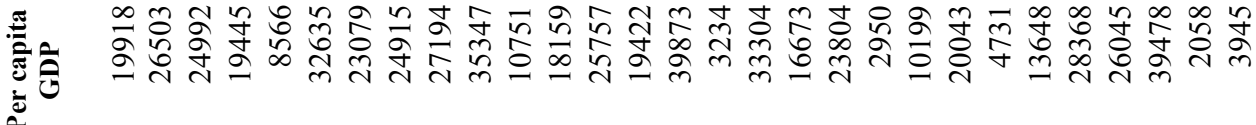

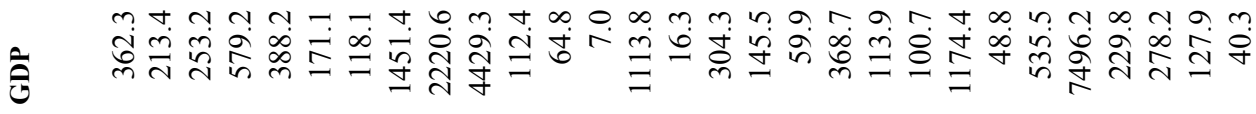

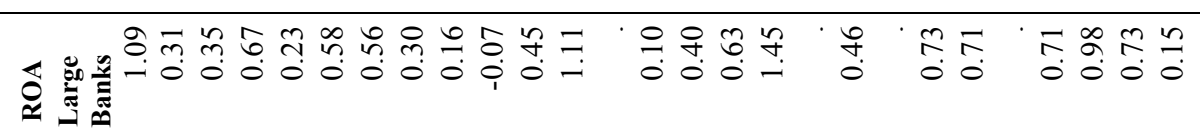

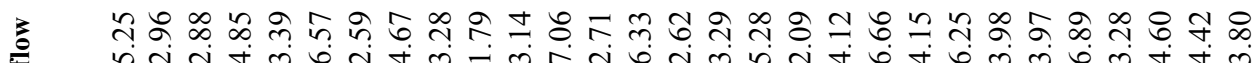

ปี

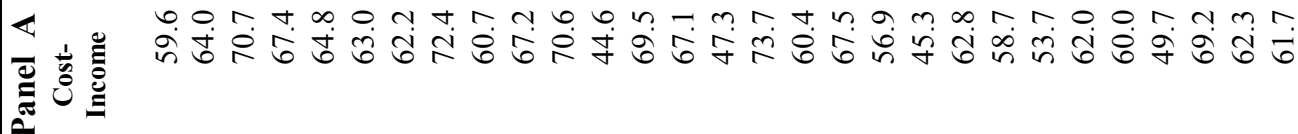

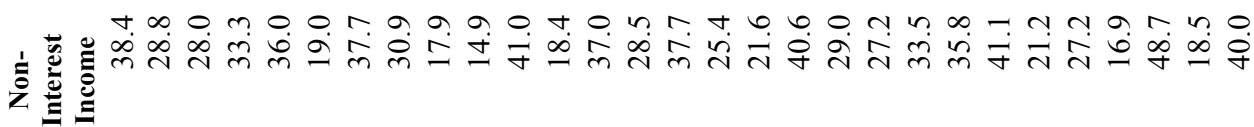

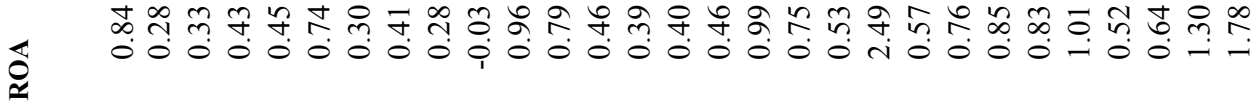

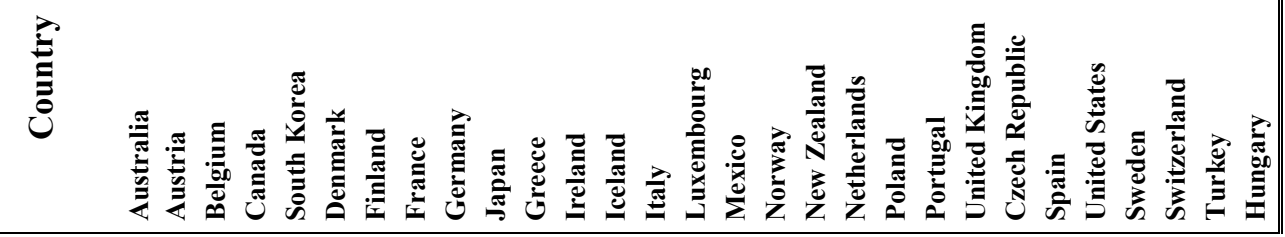




\section{The Determinants of a Bank's Decision to Expand Abroad}

The empirical model in equation (1) has been estimated using a multinomial logit specification, where the dependent variable equals 1 if the bank has only a branch in the destination county (panel A), 2 if the bank has a shareholding in the destination country (Panel $\mathrm{B})$, and zero otherwise. Panel $\mathrm{C}$ reports a $\chi^{2}$ test that coefficients of each variable are equal for branches and subsidiaries. All variables are defined in tables 4 and 5: (i) stands for individual bank data; (o) for origin country data; (b) for bilateral data; (d) for destination country data. The estimate also includes dummy variables (unreported) to account for the nature of the main activity of the bank (commercial banks, cooperative banks, medium and long term banks, real estate-mortgage banks, savings banks, specialized government credit institutions, and investment banks and securities houses). The marginal effect of each explanatory variable, measured as the change in the probability that a bank will have a branch (shareholding) in a given country (expressed in percentage points) associated with a change in the covariate from the 25 th to the 75 th percentile of the sample distribution, leaving all other variables at their sample values. In order to measure the relative importance of each factor discussed in section 3 , we computed synthetic variables (factors) as weighted averages of those included in the basic regression, with the weights given by the estimated coefficients. Then we estimated previous regressions with the factors as explanatory variables (by construction their coefficients are all equal to 1) and computed the marginal effects associated with a change in each factor from its level at the 25th to that at the 75 th percentile of the sample distribution, leaving all other factors at their sample values. Standard errors are reported in italics. The row IIA-test reports the test value on the Independence from Irrelevant Alternatives property (Hausman and Mc Fadden, 1984). The symbol *** indicates a significance level of 1 per cent or less; ** between 1 and 5 per cent; * between 5 and 10 per cent.

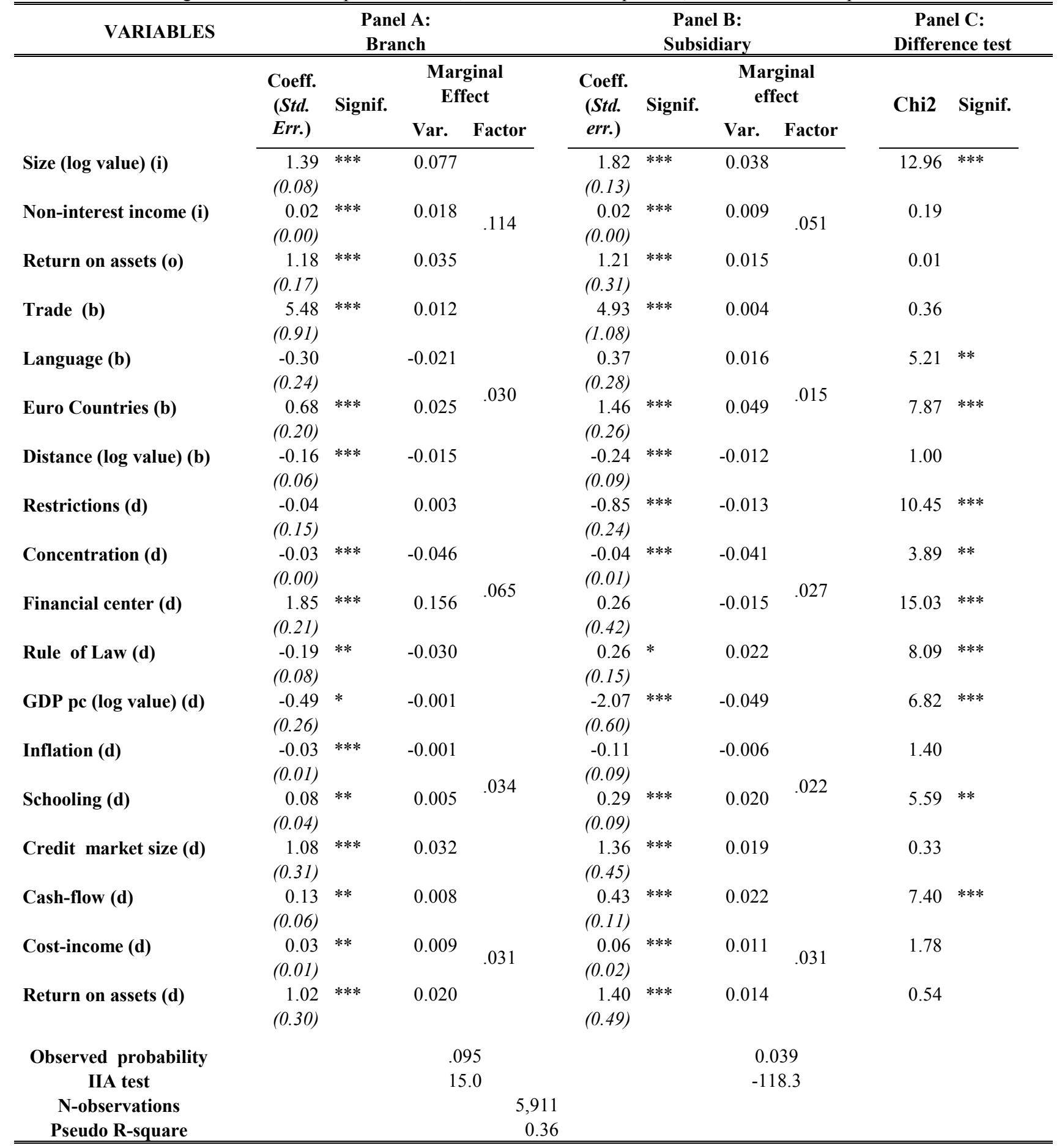




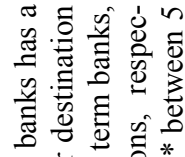

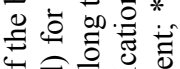
워을 융

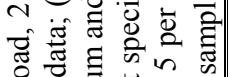

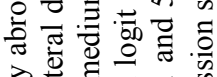

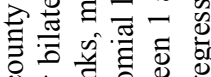
०. 을.己

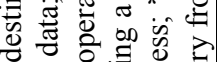

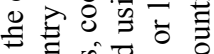

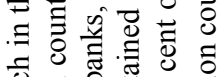

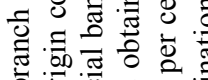

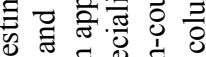

बै

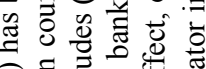
Є.

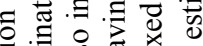

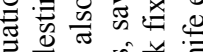

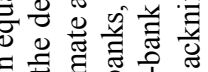
ब.

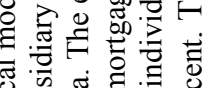

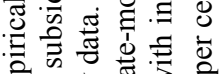

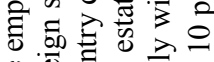

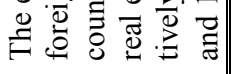

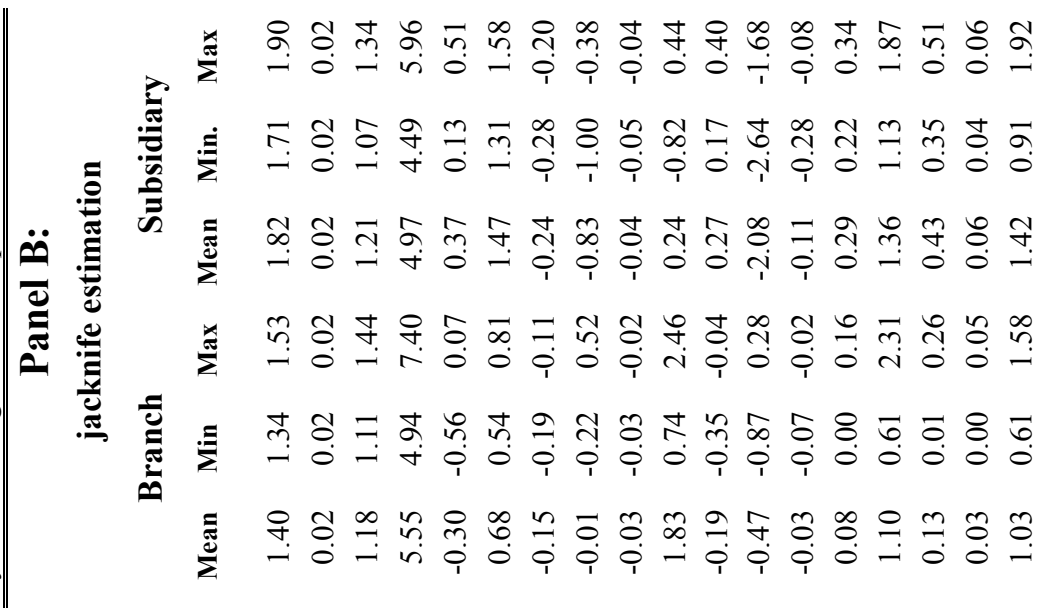

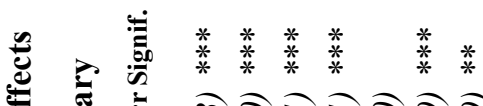

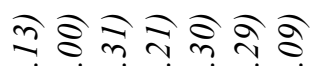

ée esee

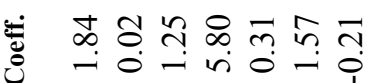

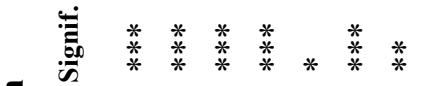

$\bar{\sigma}$
nิ
?

के के बूई ते छ

ééeje

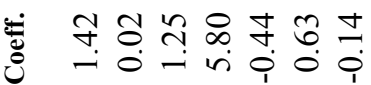

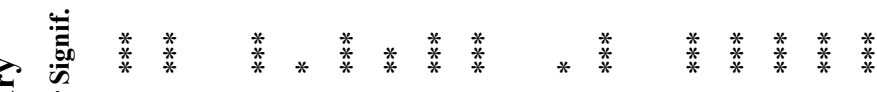

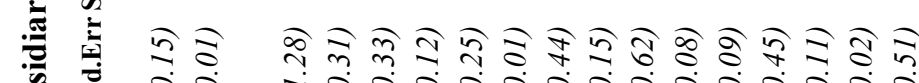

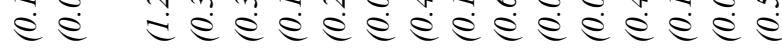

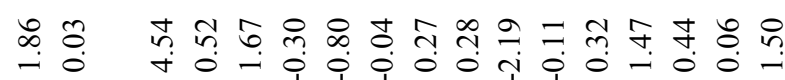

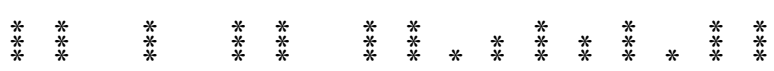
$\begin{array}{ll}\bar{\sigma} & \infty \\ \text { nे } & ?\end{array}$

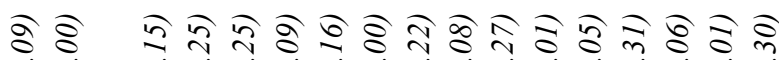

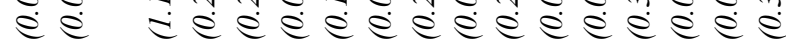

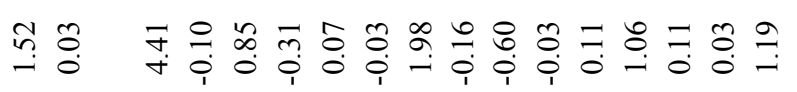

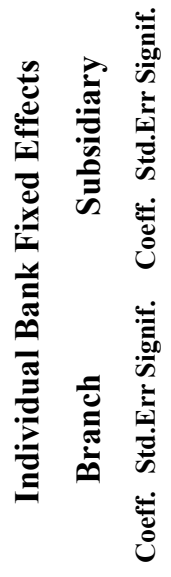

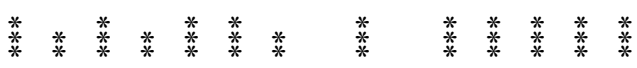

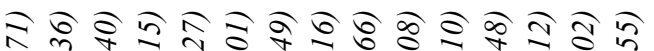
iejejejejejejeje 은

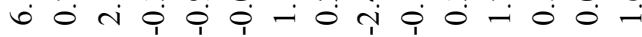

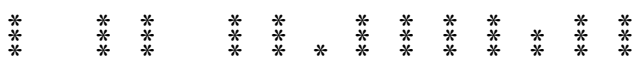
三̆

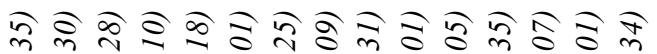

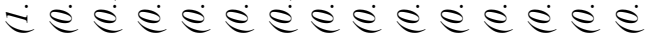

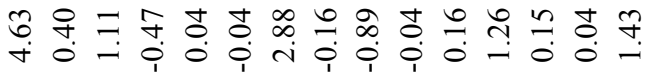

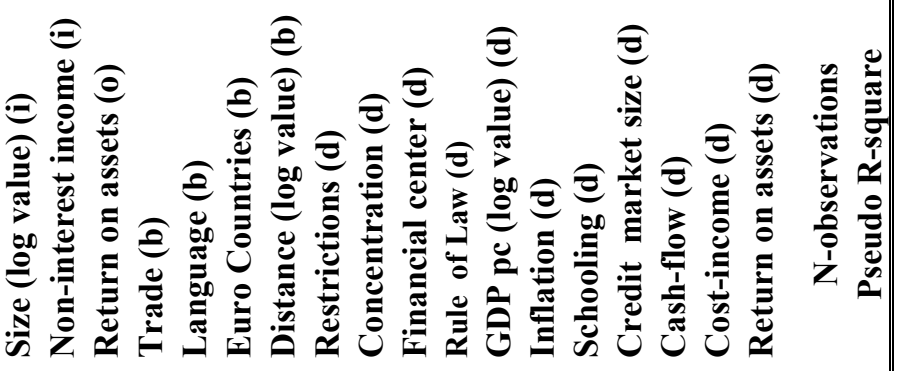

